\title{
Preparation of lactose hydrolysed milk using $\beta$-galactosidase enzyme extracted from potential Lactobacillus cultures
}

\author{
Shrushti Makwana, Subrota Hati and H M Modha
}

Received: 11 June 2018 / Accepted: 02 December 2018 / Published online: 21 February 2019

(C) Indian Dairy Association (India) 2019

\begin{abstract}
In the study, $\mathrm{pH} 6.5$ and $40^{\circ} \mathrm{C}$ were selected on the basis of maximum $\beta$-galactosidase activity produced by L.helveticus MTCC 5463 (V3), L.rhamnosus (NK2) and L.casei (NK9) during optimizing the $\mathrm{pH}$ and temperatures using Response Surface Methodology (RSM). During evaluation of lactose hydrolysis using partially purified $\beta$-galactosidase enzyme, V3 showed highest reduction of lactose and maximum production of glucose and galactose at $2 \%$ rate of $\beta$-galactosidase upto $12 \mathrm{~h}$ of incubation. Partially purified $\beta$-galactosidase enzyme showed maximum lactose hydrolysis at $2 \%$ rate of addition in sterilized reconstituted skim milk for V3, NK2 \& NK9 cultures up to $12 \mathrm{~h}$ of incubation. Lactose hydrolysed milk which were prepared using partially purified enzyme were added @ $2 \%$ in sterilized reconstituted skim milk for $12 \mathrm{~h}$ at $37^{\circ} \mathrm{C}$. Based on sensory scores, B (Commercially available enzyme sample), A (Reconstituted sterilized skim milk), and C (Partially purified $\beta$-galactosidase produced from V3) showed highest sensory score and were more acceptable compared to D (NK2), E (NK9) and F (Market sample: Lactose free milk) after $12 \mathrm{~h}$ of incubation at $37^{\circ} \mathrm{C}$ by adding $2 \%$ partially purified $\beta$-galactosidase enzyme in sterilized reconstituted skim milk.
\end{abstract}

Keywords: $\beta$-galactosidase; Lactobacillus; Lactose hydrolysed milk; Ultrasonication,

Shrushti Makwana, Subrota Hati( $\square)$

Dairy Microbiology Department, Anand Agricultural University, Anand388 110, Gujarat, India

E-mail: subrota_dt@yahoo.com

H M Modha

Dairy Technology Department, Anand Agricultural University, Anand388110 , Gujarat, India

\section{Introduction}

Lactose hydrolysis in milk and other dairy products by the enzyme, $\beta$-galactosidase [EC 3.2.1.23] is of considerable interest to the dairy industry. $\beta$-galactosidases produced by microorganisms are being used in food technology for hydrolysis of lactose in milk and milk by-products. The enzyme has attracted much attention in view of lactose intolerance in human population and due to importance of milk in human diet (Xavier et al. 2018). $\beta$-galactosidase is widely used in food industry to improve sweetness, solubility, flavor and digestibility of dairy products. The lactase enzymes most commonly used in the food industry are $\beta$-galactosidases, which are generally inhibited as glucose concentration increases (Jensen et al. 2015, Husain, 2010, Carevic et al. 2018). Enzymatic hydrolysis of lactose by $\beta$ galactosidase is one of the most popular technologies to produce lactose reduced milk and related dairy products for consumption by lactose intolerant people (Haider and Husain, 2008). $\beta$ galactosidases from bacterial sources has been widely used for the hydrolysis of lactose because of the ease of fermentation, high activity of the enzyme and good stability (Picard et al. 2005). $\beta$-galactosidase from food grade probiotic microorganisms are safe for human use. Probiotic bacteria producing high level of $\beta$ galactosidase is very significant (Chanalia et al. 2018). Lactic acid bacteria (LAB) that used as starters for production of dairy products are the main factors of fermentation and protection of fermentative foods and also have a significant role in texture and flavour of food products. Maximum production of $\beta$-galactosidase was obtained with $\mathrm{pH}$ at 6 and Temperature at $45^{\circ} \mathrm{C}$. Lactobacillus delbrueckii was showed that it is ideal for lactose intolerant people and can be used for probiotics (Sharma and Singh, 2014). Bosso et al. (2016) evaluated the enzyme from Kluyveromyces lactis (liquid) and Aspergillus oryzae (lyophilized) was investigated the temperature and $\beta$-galactosidase concentration on the lactose hydrolysis in UHT milk was higher than in skimmed milk. With respect to the thermal stability, a decrease in hydrolysis rate was observed at $\mathrm{pH} 6.0$ at $35^{\circ} \mathrm{C}$ for $K$. lactis enzyme, and at pH 6.0 at $55^{\circ} \mathrm{C}$ for the enzyme from $A$. oryzae. Chanalia et al. (2018) reported thermodynamic parameters, which were calculated and suggested that $\beta$-galactosidase is less stable at higher temperature $\left(60^{\circ} \mathrm{C}\right)$. Approximately $75 \%$ of Earths population is lactose intolerant and in India (particularly southern part of India) 
$70 \%$ of the population are lactose intolerance. To meet the challenge, lactose hydrolysed milk is an alternative solution for the proposed study. However the source of enzyme ( $\beta$ galactosidase) from biological material like LAB (Lactic acid bacteria) which is an added advantage from safety point of view having GRAS (Generally recognized as safe) status.

\section{Materials and methods}

The Lactobacillus cultures used in the present study i.e. $L$. helveticus MTCC 5463 (V3), L. rhamnosus (NK2) and L. casei (NK9) were obtained from the Culture Collection of Dairy Microbiology Department, SMC College of Dairy Science, Anand Agricultural University, Anand. The Lactobacillus cultures were propagated in sterilized reconstituted skim milk (10\% TS) and stored at $5 \pm 2{ }^{\circ} \mathrm{C}$. The transfer of stored cultures was given every week during the course of the study. Most the bacteriological media, chemicals and reagents were purchased either from HiMedia (India), Sigma (USA), SDFCL (India), Chr. Hansen (Denmark).

Optimization of $\mathrm{pH}$ and temperatures for $\beta$-galactosidase activity

All the cultures were activated by growing in MRS broth tubes. The activated cultures were added to $100 \mathrm{ml}$ MRS broth (HiMedia, India) at the rate of $2 \%$. After mixing thoroughly, the cultures were incubated at $37 \mathrm{R}$ "C for $24 \mathrm{~h}$. After that, samples were taken out for $\beta$-galactosidase activity.

\section{Enzyme Extraction}

After $24 \mathrm{~h}$, the cells were harvested by centrifuging at $5000 \mathrm{rpm}$ for $15 \mathrm{~min}$ at $4^{\circ} \mathrm{C}$. The supernatant was considered to be containing extracellular enzymes. The cell pellet were crushed and washed twice with a $0.05 \mathrm{M}$ sodium phosphate buffer $(\mathrm{pH}$ 6.8) and centrifuged at $5000 \mathrm{rpm}$ for $15 \mathrm{~min}$ at $4^{\circ} \mathrm{C}$. The washed pellets were resuspended in $10 \mathrm{~mL}$ of $0.05 \mathrm{M}$ phosphate buffer $(\mathrm{pH}$ 6.8) for intracellular enzyme extraction using sonication method (Makwana et al. 2017; Prasad et al. 2013):

\section{Sonication treatment}

The cell suspensions were sonicated for 5 min intervals (pulse 15 seconds Off / 30 seconds On at 55\% amplitudes) in ice bath using sonicator (LABMAN, India), according to the method mentioned by Prasad et al. (2013). The extract was then centrifuged at $5000 \mathrm{rpm}$ under $4^{\circ} \mathrm{C}$ for $15 \mathrm{~min}$ and the supernatant containing the crude enzyme was stored at $-20^{\circ} \mathrm{C}$ until used for enzyme assays.

\section{Enzyme assay}

The $\beta$-galactosidase was determined by the reaction mixture composed of $0.5 \mathrm{~mL}$ of supernatant containing extracted enzyme and $2.0 \mathrm{~mL}$ of $15 \mathrm{mM}$ O-nitrophenyl $\beta$-D-galactopyranoside
(ONPG) in $0.05 \mathrm{M}$ sodium phosphate buffer (different $\mathrm{pH}$ ). After incubation for $20 \mathrm{~min}$ at different incubation temperature, $0.5 \mathrm{~mL}$ of $0.1 \mathrm{M}$ sodium carbonate was added to the mixture to stop the reaction. Absorbance was measured at $420 \mathrm{~nm}$ with a spectrophotometer (Systronics PC based double beam spectrophotometer 2202, India) (Makwana et al. 2017; Prasad et al. 2013). Optimization of $\mathrm{pH}$ and Temperature were carried out using RSM.

\section{Preparation of lactose hydrolysed milk using $\beta$-galactosidase}

Sterilized skim milk added with i.e. $1.0,1.5 \& 2 \%$ of partially purified $\beta$-galactosidase enzyme and incubated at $37^{\circ} \mathrm{C}$ for $0,4,8 \& 12 \mathrm{~h}$. After incubations, $2 \mathrm{ml}$ sample and $1.5 \mathrm{ml}$ double distilled water were kept in water bath at $60^{\circ} \mathrm{C}$ for $10 \mathrm{~min}$. Then, $0.25 \mathrm{ml}$ of Carrez 1 (Potassium ferrocynide), $0.25 \mathrm{ml}$ of Carrez 2 (Zinc acetate) and $1 \mathrm{ml}$ of acetonitrile were added, gently mixed it and kept in incubation at $37^{\circ} \mathrm{C}$ for $1 \mathrm{~h}$. After $1 \mathrm{~h}$, the samples were centrifuged at $5000 \mathrm{rpm}$ for $10 \mathrm{~min}$ under $20^{\circ} \mathrm{C}$. The supernatant were filtered, using syringe filter $(0.22 \mu$ syringe filter). Samples were kept at $20^{\circ} \mathrm{C}$ until measured through RP-HPLC (Shimadzu LC-20, Japan) for lactose, glucose and galactose.

\section{Estimation of Lactose, Glucose and Galactose through RP-HPLC}

$20 \mu 1$ processed sample was injected in the HPLC (Shimadzu LC20, Japan) through microinjector (HAMILTON Bonaduz AG, Switzerland. RP-HPLC (Shimadzu LC-20, Japan) was performed as described by Rodriguez-Figueroa et al. (2012); Papadimitriou et al. (2007). An isocratic HPLC system was used fitted with C18 column (Se Quant ${ }^{\circledR}$ ZIC $®$-cHILIC) white pore analytic column $(3 \mu, 250 \times 4.6 \mathrm{~mm})$. Sample was applied using microinjector (HAMILTON Bonaduz AG, Switzerland) with $20 \mu 1$ loop. Eluent was $1 \%(\mathrm{v} / \mathrm{v})$ of TFA in mixture of 70:30 of acetonitrile and deionised water. Separation was conducted at room temperature at flow rate $0.5 \mathrm{ml} / \mathrm{min}$ with eluent for $25 \mathrm{~min}$. Absorbance of elute was monitored through refractive index detector (Shimadzu, RID-10A). All the samples were analysed in triplicate.

\section{Sensory evaluation}

Lactose hydrolysed milk was prepared adding partially purified enzymes@2\% in sterilized reconstituted skim milk and incubated for $12 \mathrm{~h}$ at $37^{\circ} \mathrm{C}$. After incubation, lactose hydrolysed milk was stored in refrigeration condition $\left(4 \pm 2^{\circ} \mathrm{C}\right)$. The overall quality and acceptability of Lactose hydrolysed milk samples were assessed by a consumer oriented panel after $12 \mathrm{~h}$ of incubation. All products were coded and arranged in random order. The product was subjected to the sensory evaluation by an expert trained panel of seven judges for colour and appearance, odour, flavour and taste and body (consistency) on the basis of 100 point score card prescribed by BIS (IS:7768, 1975). Six combinations were decided (3: cultures, 1: CAE and one positive and negative control) in the study. After $12 \mathrm{~h}$ of incubation at $37^{\circ} \mathrm{C}$, the lactose hydrolysed milk stored at refrigeration temperature and then were brought to 
$10^{\circ} \mathrm{C}$ before providing to the panelists. The score given by panelists on 100 point score card were considered for judging the acceptability of the product.

\section{Results and discussion}

A statistical software programme (Design Expert 8.0.3) was employed to optimize $\mathrm{pH}$ and Temperature. Two factors were in the range of $\mathrm{pH}(5.5$ to 7.5$)$ and temperature $\left(30\right.$ to $\left.50^{\circ} \mathrm{C}\right)$. The software suggested 13 runs and the response obtained from 13 runs by V3, NK2 and NK9 has been shown in Table 1 .

\section{Influence of different Levels of $\mathrm{pH}$ and temperature on $\beta$ - galactosidase activity produced by V3, NK2 and NK9 cultures}

In any enzymatic assay, $\mathrm{pH}$ and temperature play an important role in deciding the optimum activity of enzyme. The parameters chosen to assess the quality of $\beta$-galactosidase activity were $\mathrm{pH}$ and temperature. The data of the $\beta$-galactosidase enzyme along with their formulations as per their run order were presented in table 1 . The quadratic model for $\mathrm{pH}$ and temperature were fitted through successive regression analysis. The Model $\mathrm{F}$ values for $\mathrm{pH}$ and temperature of $\mathrm{V} 3, \mathrm{NK} 2$ and NK9 cultures were 41.54, 231.24 and 63.37 respectively as shown in Table 2 . The calculated $F$ values greater than the Table $F$ values at $5 \%$ level of confidence indicates the significance of model terms. Furthermore, the coefficient of determination $\left(\mathrm{R}^{2}\right)$ which reflects the proportion of variability in data explained or accounted by the model for $\mathrm{pH}$ and temperature of V3, NK2 and NK9 cultures were $0.9674,0.9940$ and 0.9784 respectively. A larger $\mathrm{R}^{2}$ value approaching to 1.00 suggests a better fit of the quadratic model. The adequate precision measures the signal to noise ratio, the value of which should be greater than 4.0. In the present study, the adequate precision value for $\mathrm{pH}$ and temperature of $\mathrm{V} 3, \mathrm{NK} 2$ and $\mathrm{NK} 9$ cultures were $14.965,32.731$ and 17.655 respectively which were greater than 4, highlighting the suitability of the model to navigate the design.

\section{Effect of $\mathrm{pH}$ and temperature on $\beta$-galactosidase activity}

The $\beta$-galactosidase activity scores for $\mathrm{V} 3$ culture were ranged from 0.641 (O.D.) to 3.452 (O.D.), followed by NK2 culture ranged from 0.388 (O.D) to 2.984 (O.D) and NK9 culture ranged from $0.556(\mathrm{O} . \mathrm{D})$ to $3.14(\mathrm{O} . \mathrm{D})$. The $\beta$-galactosidase activity scores were found best at $\mathrm{pH} 6.5$ and temperature $40 \mathrm{R}$ " $\mathrm{C}(\mathrm{V} 3=$ run $3, \mathrm{NK} 2=$ run $5, \mathrm{NK} 9=$ run 7) while scored lowest for $\mathrm{pH} 7.9$ and temperature 40R" $\mathrm{C}$ for V3 and NK2 cultures and $\mathrm{pH} 5.5$ and temperature 30R" $\mathrm{C}$ for NK9 culture (Table 2). The values were presented in Table 2 which revealed that $\mathrm{pH}$ and temperature had significant negative effect on $\beta$-galactosidase activity on quadratic level. The square of factor (quadratic) indicates the effect of factors at highest level used in the product preparation. A significant $(\mathrm{P}>0.01)$ negative effect on V3, NK2 and NK9 cultures were found with the higher level of $\mathrm{pH}\left(\mathrm{A}^{2}\right)$ and temperature $\left(\mathrm{B}^{2}\right)$.

$\beta$-galactosidase activity for $\mathrm{V} 3$ culture = $+3.37+0.058 \mathrm{~A}+0.046 \mathrm{~B}+0.13 \mathrm{AB}-1.41 \mathrm{~A}^{2}-0.83 \mathrm{~B}^{2}$

$\beta$-galactosidase activity for $\mathrm{NK} 2$ culture $=+2.97+0.036 \mathrm{~A}+7.124 \mathrm{E}-$ 003B-0.029AB-1.31 $\mathrm{A}^{2}-0.99 \mathrm{~B}^{2}$

$\beta$-galactosidase activity for $\mathrm{NK} 9$ culture $=+3.07+0.029 \mathrm{~A}-2.359 \mathrm{E}-$ $003 \mathrm{~B}+0.0 .046 \mathrm{AB}-1.33 \mathrm{~A}^{2}-0.90 \mathrm{~B}^{23 \ldots}$

Where, $\mathrm{A}$ and $\mathrm{B}$ refer to $\mathrm{pH}$ and temperature $\left({ }^{\circ} \mathrm{C}\right)$ respectively. The response surface plots for the values obtained were shown in Fig. 1 which are based on the above model with varying levels of the two variables studied within the experimental range.

Table 1 Experimental design matrix and $\beta$-galactosidase activity scores at different $\mathrm{pH}$ and temperature of V3, NK2 and NK9 cultures

\begin{tabular}{lllllc}
\hline Run & A: $\mathrm{pH}$ & $\mathrm{B}:$ Temperature $\left({ }^{\circ} \mathrm{C}\right)$ & $\begin{array}{l}\beta \text {-galactosidase } \\
\text { activity (O. D) V3 } \\
\text { Culture }\end{array}$ & $\begin{array}{l}\beta \text {-galactosidase } \\
\text { activity (O. D) } \\
\text { NK2 Culture }\end{array}$ & $\begin{array}{c}\beta \text {-galactosidase } \\
\text { activity (O. D) } \\
\text { NK9 Culture }\end{array}$ \\
\hline 1 & 5.5 & 50 & 0.750 & 0.501 & 0.588 \\
2 & 5.5 & 30 & 0.708 & 0.464 & 0.556 \\
3 & 6.5 & 40 & 3.452 & 2.976 & 3.03 \\
4 & 7.5 & 30 & 0.846 & 0.736 & 0.595 \\
5 & 6.5 & 40 & 3.368 & 2.984 & 2.991 \\
6 & 5.1 & 40 & 0.865 & 0.486 & 0.603 \\
7 & 6.5 & 40 & 3.371 & 2.98 & 3.14 \\
8 & 6.5 & 26 & 1.985 & 1.043 & 1.546 \\
9 & 7.9 & 40 & 0.641 & 0.388 & 0.584 \\
10 & 6.5 & 54 & 1.829 & 1.113 & 1.358 \\
11 & 7.5 & 50 & 1.396 & 0.657 & 0.81 \\
12 & 6.5 & 40 & 3.366 & 2.95 & 3.121 \\
13 & 6.5 & 40 & 3.313 & 2.942 & 3.045 \\
\hline
\end{tabular}



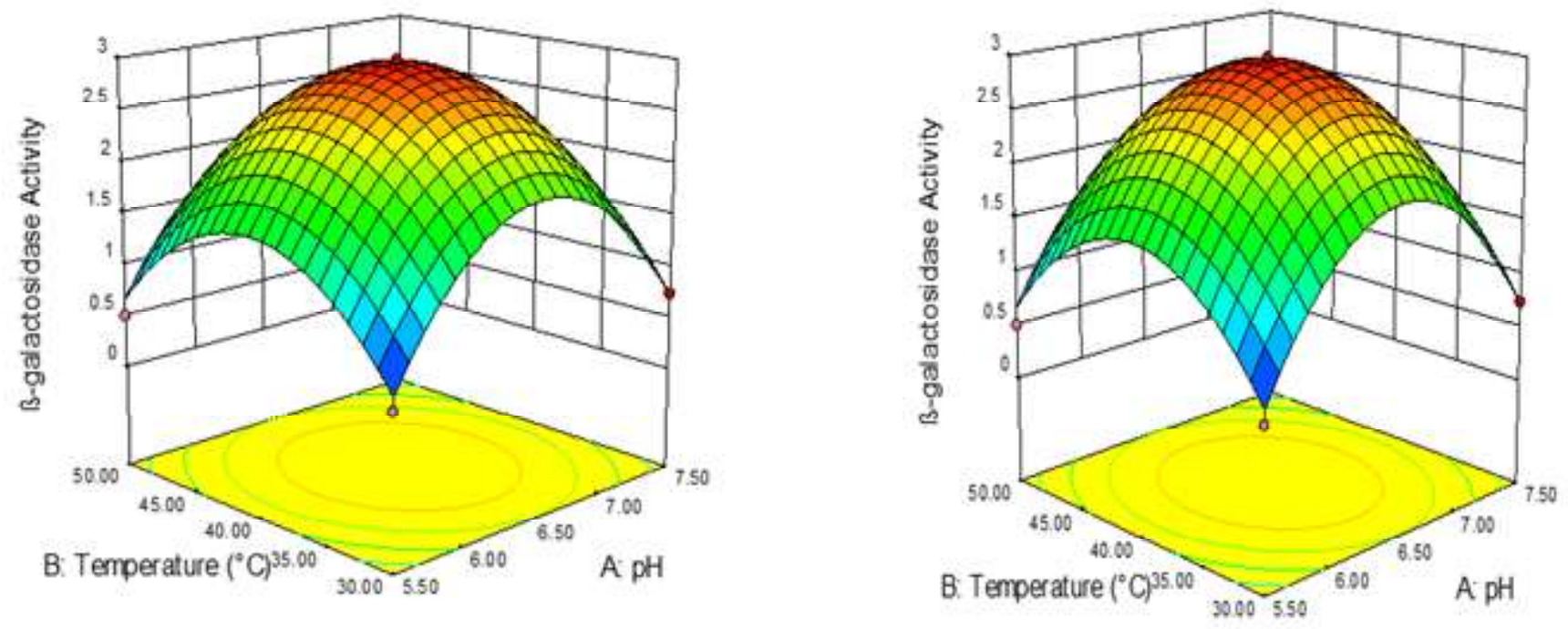

Fig. 1 Response surface of $\beta$-galactosidase activity score as influenced by level of $\mathrm{pH}$ and temperature of $\mathrm{A}=\mathrm{V} 3, \mathrm{~B}=\mathrm{NK} 2$, $\mathrm{C}=\mathrm{NK}$ 9 cultures

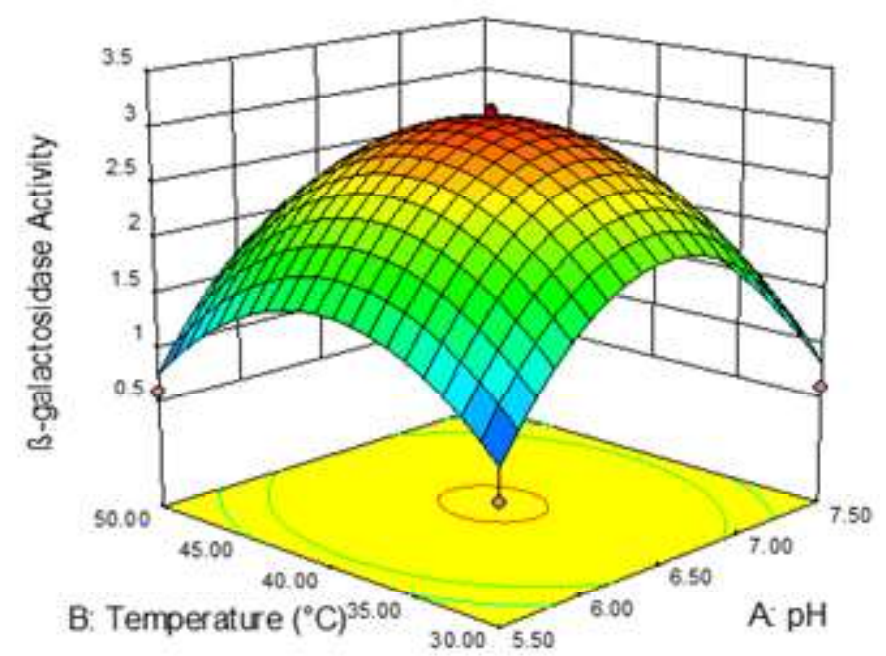

Table 2 Partial Coefficients of regression equations of suggested models for $\beta$-galactosidase activity scores at different $\mathrm{pH}$ and temperature

\begin{tabular}{lllll}
\hline Factor & & $\begin{array}{l}\beta \text {-galactosidase } \\
\text { activity V3 Culture }\end{array}$ & $\begin{array}{l}\beta \text {-galactosidase } \\
\text { activity NK2 Culture }\end{array}$ & $\begin{array}{l}\beta \text {-galactosidase } \\
\text { activity NK9 Culture }\end{array}$ \\
\hline Linear & $\mathrm{A}$ & 0.0584 & 0.0362 & 0.0293 \\
& $\mathrm{~B}$ & 0.0464 & 0.0071 & -0.0024 \\
Interactive & $\mathrm{AB}$ & 0.127 & -0.029 & 0.0458 \\
Quadratic & $\mathrm{A}^{2}$ & $-1.412^{*}$ & $-1.3067^{*}$ & $-1.332^{*}$ \\
& $\mathrm{~B}^{2}$ & $-0.835^{*}$ & $-0.9862^{*}$ & $-0.903^{*}$ \\
$\mathrm{R}^{2}$ & 0.9674 & 0.9940 & 0.9784 \\
Model f value & & 41.54 & 231.24 & 63.37 \\
Intercept & 3.374 & 2.9664 & 3.0654 \\
APV & 14.965 & 32.731 & 17.655 \\
Model & Quadratic & Quadratic & Quadratic \\
$* \mathrm{P}<0.01 ;$ APV= Adequate Precision Value; & $\mathrm{R}^{2}=$ Coefficient of determination & \\
\hline
\end{tabular}

Optimization of $\mathrm{pH}$ and temperature for $\beta$-galactosidase enzyme production
Optimization of $\mathrm{pH}$ and temperature for $\beta$-galactosidase production were carried out with the objective of determining the best possible combination(s) of $\mathrm{pH}$ and temperature $\left({ }^{\circ} \mathrm{C}\right)$ that would lead to maximum $\beta$-galactosidase production. The goals 
Fig. 2 Effect of partially purified $\beta$ galactosidase on reduction of lactose

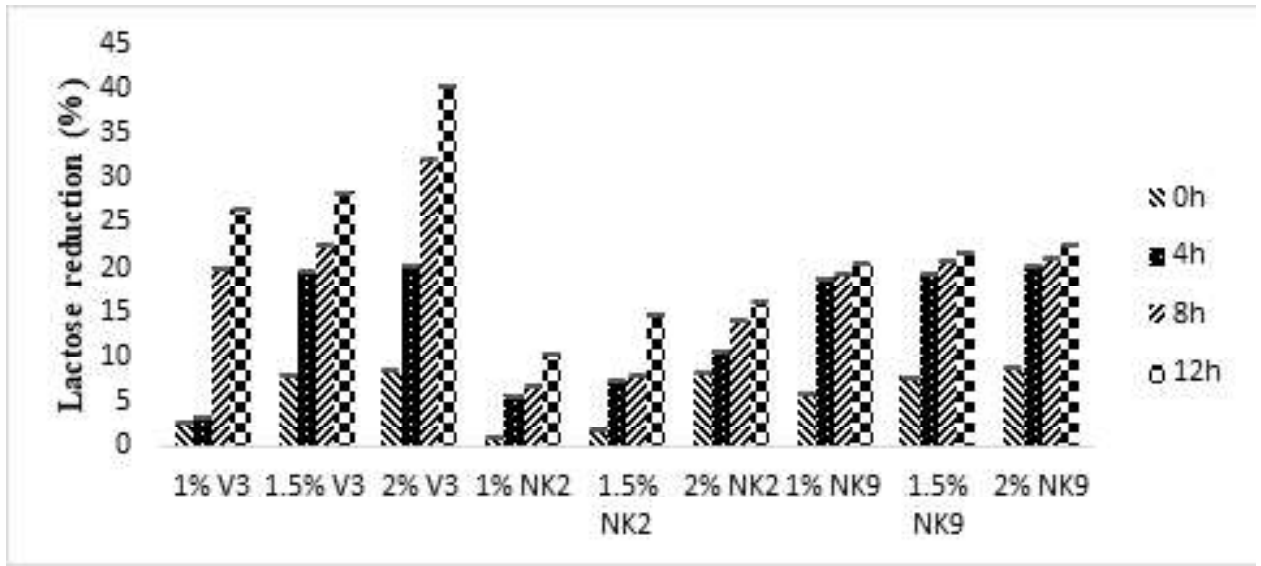

Fig. 3 Effect of partially purified $\beta$ galactosidase on production of glucose

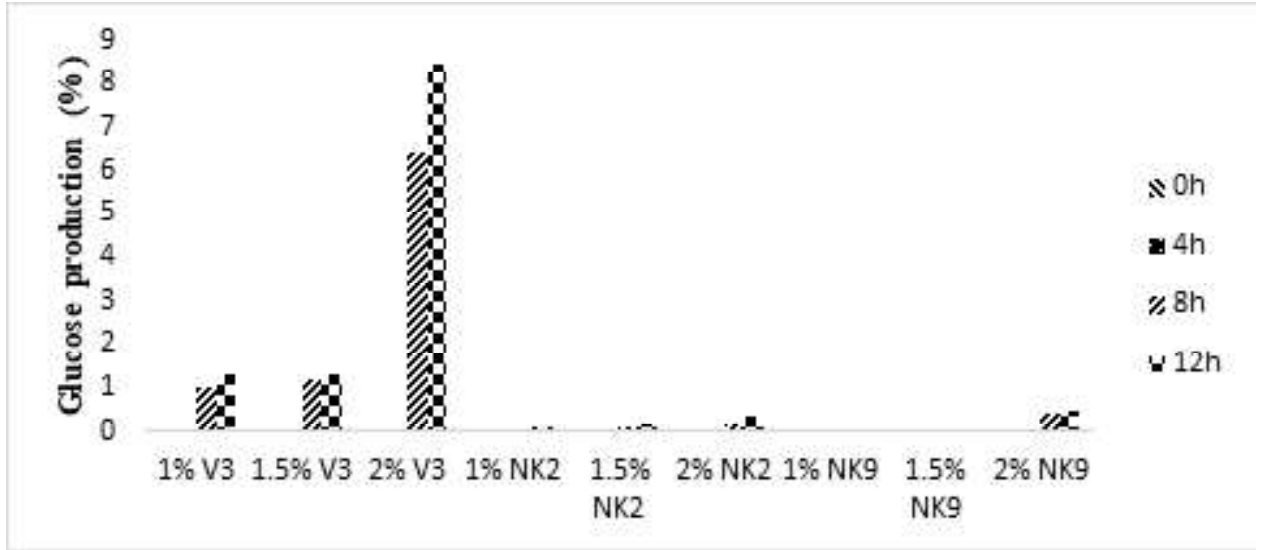

Table 3 Criteria/responses chosen for process optimization of $\mathrm{pH}$ and temperature for $\beta$-galactosidase enzyme production

\begin{tabular}{lllllll}
\hline Sr. No & Constrain & Units & Goal & $\begin{array}{l}\text { Lower } \\
\text { limit }\end{array}$ & $\begin{array}{l}\text { Upper } \\
\text { limit }\end{array}$ & Level of importance \\
\hline 1 & pH & - & In range & 5.5 & 7.5 & 3 \\
2 & Temperature & ${ }^{\circ} \mathrm{C}$ & In range & 30 & 50 & 3 \\
3 & $\beta$-galactosidase activity (V3) & OD & Maximum & 0.641 & 3.452 & 3 \\
4 & $\beta$-galactosidase activity (NK2) & OD & Maximum & 0.388 & 2.984 & 3 \\
5 & $\beta$-galactosidase activity (NK9) & OD & Maximum & 0.556 & 3.14 & 3 \\
\hline
\end{tabular}

that were set for obtaining the best combination were illustrated in Table 3. The ranges of the minimum and maximum values for each of the attribute observed in the previous phase for each of the selected constraints/responses were fed to the software package. The data were analyzed in Design Expert Package. Considering the constraints and their upper and lower limits, the RSM suggested the one most suited solution as shown in Table 4.

The final enzyme assay was conducted by employing the formulation as shown in Table 4 . The result was suggested by the software (Table 4). Both values were nearer to suggested values and it is not possible to control temperature and $\mathrm{pH}$ up to 2 decimal places. Thus, we carried out experiment at $\mathrm{pH} 6.5$ and temperature i.e. $40^{\circ} \mathrm{C}$ in actual conditions. We found the highest $\beta$-galactosidase activity produced by $\mathrm{V} 3, \mathrm{NK} 2$ and NK9 cultures at above conditions. The process was replicated seven times. The selected factors and the average values of the results were derived. The values of the selected constraints/responses as shown in Table 4 were compared statistically using paired t-test with that of the predicted values as shown in Table 4 . The calculated values of all these selected constraints suggest that the calculated values of ' $t$ ' for all the constraints were less than the table values, thus it was inferred that there was no significant $(\mathrm{P}>0.05)$ difference between the predicted and actual values of responses as shown in Table 5. 
Fig. 4 Effect of partially purified $\beta$ galactosidase on production of galactose

Fig. 5 Sensory score of Lactose hydrolysed milk prepared using partially purified $\beta$-galactosidase enzyme extracted from Lactobacillus cultures
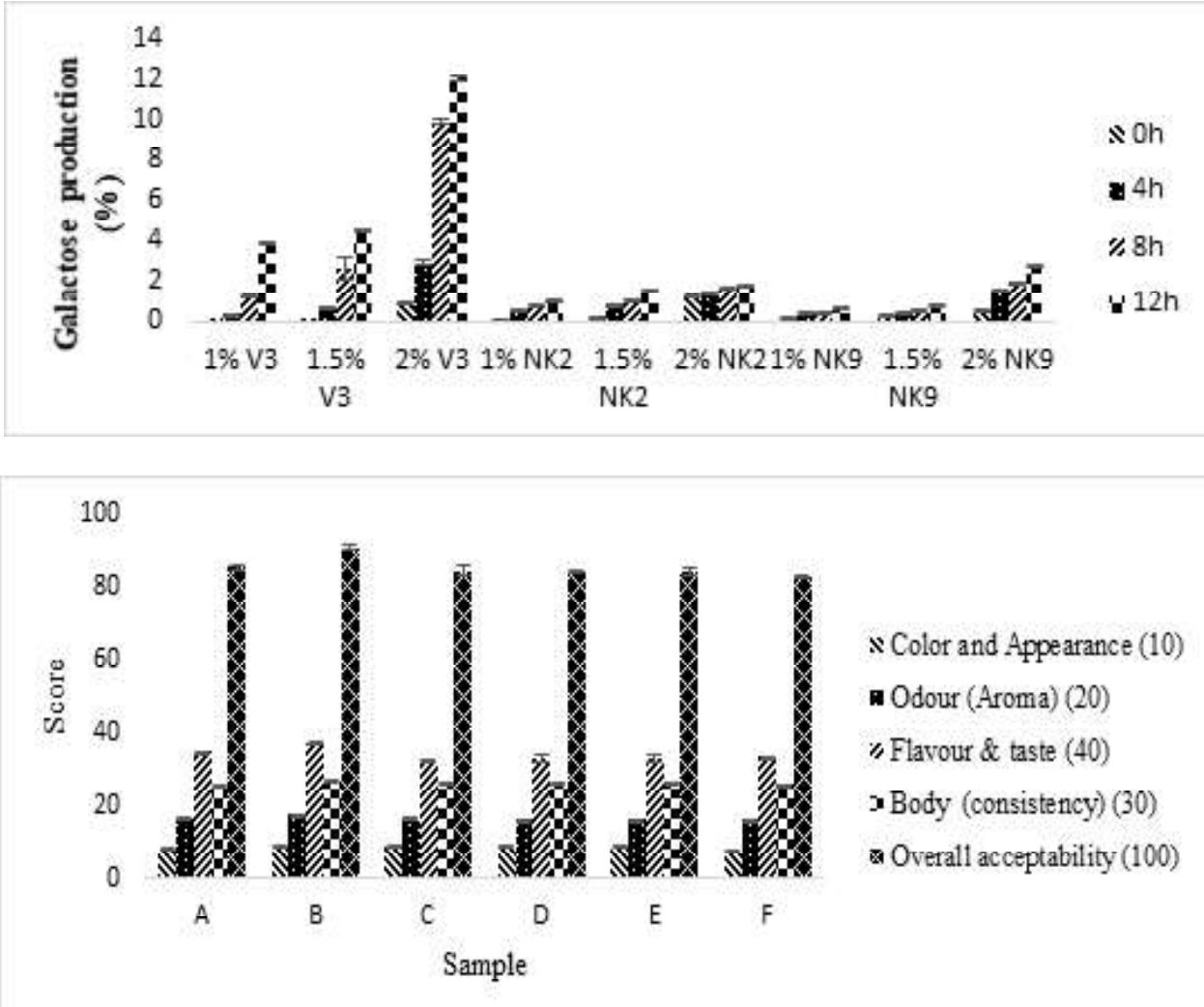

Table 4 Suggested solution for analysis of $\beta$-galactosidase enzyme of V3, NK2 and NK9 cultures

\begin{tabular}{lllll}
\hline Solution for & Solution & & Desirability \\
\cline { 2 - 4 } Different cultures & $\mathrm{pH}$ & Temperature $\left({ }^{\circ} \mathrm{C}\right)$ & OD & 0.973 \\
\hline V3 & 6.52 & 40.29 & 3.375 & 0.993 \\
NK2 & 6.51 & 40.04 & 2.966 & 0.971 \\
NK9 & 6.51 & 39.98 & 3.066 & \\
\hline
\end{tabular}

Table 5 Comparison of predicted $\mathrm{v} / \mathrm{s}$ actual values of responses used for process optimization of $\mathrm{pH}$ and temperature for $\beta$ galactosidase enzyme production

\begin{tabular}{lllllll}
\hline Cultures & Responses & $\begin{array}{l}\text { P- } \\
\text { value }\end{array}$ & $\begin{array}{l}\text { Predicted } \\
\text { value }\end{array}$ & $\begin{array}{l}\text { Actual } \\
\text { value }\end{array}$ & $\begin{array}{l}\text { Calculated t- } \\
\text { value }\end{array}$ & Level of significance \\
\hline V3 & $\beta$-galactosidase activity & 0.4827 & 3.38 & 3.42 & 0.7480 & NS \\
NK2 & $\beta$-galactosidase activity & 0.7319 & 2.9700 & 2.9743 & 0.3594 & NS \\
NK9 & $\beta$-galactosidase activity & 0.5411 & 3.0600 & 3.0343 & 0.6478 & NS \\
\hline
\end{tabular}

Predicted values of Design Expert 8.0.3 package

@. Actual values (average of seven trials) of the optimized product $\mathrm{t}$-values at $5 \%$ level of significance

NS $=$ Non Significant

Tabulated t-value $=2.447$

It was therefore confirmed that the selected combination of the factors was the best in terms of the responses delineated at the study.

Rajakala and Karthigai, (2006) evaluated that optimizing the conditions for whey lactose hydrolysis to prepare whey based soups or syrups. $\beta$-galactosidase enzyme was extracted from Kluvyeromyces maxianus and partially purified. The whey lactose hydrolysis was carried out at two different temperatures, i.e. 25 and $37^{\circ} \mathrm{C}$, using whey with different $\mathrm{pH}(6.6$ and 7.0$)$. Out of eight combinations of alkali metal ions $\left(\mathrm{K}^{+}, \mathrm{Na}^{+}\right), \mathrm{pH}(6.6$ and 7.0$)$ and 
temperature $\left(25\right.$ and $\left.37^{\circ} \mathrm{C}\right)$, yield increased lactose hydrolysis that of $\mathrm{Na}^{+}$ions. $\mathrm{pH} 7.0$ was found to be effective in lactose hydrolysis than $\mathrm{pH}$ 6.6. Hydrolysis incubation temperature $\left(37^{\circ} \mathrm{C}\right)$ showed more hydrolysis percentage than $25 \mathrm{R}^{\prime} \mathrm{C}$. From the above results, it may be concluded that $\mathrm{pH}(7.0)$, temperature $\left(37^{\circ} \mathrm{C}\right)$ and alkali metal ion $\left(\mathrm{K}^{+}\right)$combination yielded the possible highest lactose hydrolysis percentage (86.8). This experimental result has similarity with our results. In another study, Ustok et al. (2010) evaluated that $\beta$-galactosidase produced by pure and mixed cultures of Streptococcus thermophilus 95/2 (St 95/2) and Lactobacillus delbrueckii sp bulgaricus 77 (Lb 77) isolated from the Toros mountain region of Turkey, were characterised with respect to their biochemical and thermal properties. Optimum $\mathrm{pH}$ and temperature for maximum activity were determined and these enzymes were stable in the $\mathrm{pH}$ range 7-9 and in the temperature range $20-37^{\circ} \mathrm{C}$, retaining $80-90 \%$ of their initial activities. The inactivation energies of $\beta$-galactosidase from $\mathrm{Lb} 77$, St 95/2 and mixed culture (Lb 77 and St 95/2) were 51.3, 44.0 and $48.3 \mathrm{kcal} \mathrm{mol}$ ${ }^{1}$, respectively. Moreover, thermodynamic (DG, DS, DH) and kinetic constants $\left(\mathrm{K}_{\mathrm{m}}\right.$ and $\left.\mathrm{V}_{\text {max }}\right)$ were determined and effects of metal ions were investigated. As a result, these enzymes could be considered as potential candidates for lactose hydrolysis of milk and milk products.

\section{Preparation of lactose hydrolysed milk using $\beta$-galactosidase}

The $\beta$-galactosidase enzyme extracted from selected Lactobacillus cultures, i.e. V3, NK2 and NK9 were statistically analysed for the different time intervals of incubations along with different $\%$ addition of enzyme for evaluating the production of lactose hydrolysed milk. Lactose reduction and glucose \& galactose production by $\mathrm{V} 3, \mathrm{NK} 2$ and $\mathrm{NK} 9$ in sterilized reconstitute skim milk at different times $(0,4,8$ and $12 \mathrm{~h})$ with varying concentrations of enzyme (1, 1.5 and $2 \%$ ) were represented in Fig. 2, Fig. 3 and Fig. 4 respectively.

In the Fig. 2, Lactose reduction ( $\%$ ) by V3 culture was significantly $(\mathrm{P}<0.05)$ increased at $2 \%$ rate of $\beta$-galactosidase enzyme after $12 \mathrm{~h}$ of incubation. Lactose reduction (\%) was significantly higher at the rate of $2 \% \beta$-galactosidase enzyme after $12 \mathrm{~h}$ of incubation for V3 $(25.445 \%)$ than NK2 $(12.474 \%)$ and NK9 $(20.750 \%)$ as compared to $1.5 \%$ and $1 \%$ respectively. Significantly maximum lactose reduction (\%) was also observed at $12 \mathrm{~h}$ of incubation $(22.511 \%)$, followed by $8 \mathrm{~h}(18.402 \%)$ and $4 \mathrm{~h}(14.064 \%)$. From the Fig. 2, it was also observed that lactose reduction (\%) of V3, NK2 and NK9 cultures were significantly $(\mathrm{P}<0.05)$ increased with the different inoculation rates (1,1.5 and $2 \%$ ) along with incubation periods $(0,4,8$ and $12 \mathrm{~h})$.

In the Fig. 3, glucose production (\%) by V3 was significantly $(\mathrm{P}<0.05)$ increased at $2 \%$ rate of $\beta$-galactosidase after $12 \mathrm{~h}$ of incubation. Glucose production (\%) was significantly highest at $2 \%$ rate of $\beta$-galactosidase after $12 \mathrm{~h}$ of incubation for $\mathrm{V} 3(3.720$ $\%)$, NK2 (0.134\%) and NK9 $(0.214 \%)$ as compared to $1.5 \%$ and
$1 \%$ respectively. Significantly maximum glucose production (\%) was also observed after $12 \mathrm{~h}$ of incubation $(1.345 \%)$, followed by $8 \mathrm{~h}(1.034 \%)$ and $4 \mathrm{~h}(0.010 \%)$. From the Fig. 3 , it was also observed that glucose production (\%) of V3, NK2 and NK9 cultures were significantly $(\mathrm{P}<0.05)$ increased with the different inoculation rates (1, 1.5 and $2 \%)$ along with incubation periods $(0,4,8$ and $12 \mathrm{~h})$.

Galactose production $(\%)$ by V3 was significantly $(\mathrm{P}<0.05)$ increased at $2 \%$ rate of $\beta$-galactosidase after $12 \mathrm{~h}$ of incubation (Fig. 4). Galactose production (\%) was significantly maximum at $2 \%$ rate of $\beta$-galactosidase addition after $12 \mathrm{~h}$ of incubation for V3 (6.467\%), NK2 (1.567\%) and NK9 (1.747\%), compared to 1.5 $\%$ and $1 \%$ respectively. Significantly maximum galactose production (\%) was also observed after $12 \mathrm{~h}$ of incubation $(3.246$ $\%)$, followed by $8 \mathrm{~h}(2.273 \%)$ and $4 \mathrm{~h}(1.048 \%)$. From the Fig. 4 , it was also found that galactose production (\%) of V3, NK2 and NK9 cultures were significantly $(\mathrm{P}<0.05)$ increased with the different inoculation rate $(1,1.5$ and $2 \%)$ along with incubation periods $(0,4,8$ and $12 \mathrm{~h})$.

Sarah et al. (2012) evaluated the correct labelling of dairy foods as "lactose-free" requires a suitably sensitive and valid analytical method for the quantification of lactose in complex food matrices. Thus, an RP-HPLC method for the simultaneous determination of lactose, glucose and galactose in original skim milk was investigated. The samples derived from an enzymatic lactose hydrolysis approach $(0.5 \mathrm{~L})$ using the commercial $\beta$-galactosidase Godo-YNL2. After derivatisation with p-aminobenzoic acid and sodium cyanoborohydride, the samples were injected on a RPC18 column. Tetrabutylammonium hydrogen sulphate was used as the ion-pair reagent in the eluent system. The sugars were quantified using photometric (UV; $303 \mathrm{~nm}$ ) and fluorescencedetection ( $\lambda$ ex $313 \mathrm{~nm}, \lambda$ em $358 \mathrm{~nm}$ ). The overall run time was 27 $\mathrm{min}$. The limits of detection (LOD) were estimated at $2 \mathrm{mg} \mathrm{L}$ "1 (UV detection) and at $0.13 \mathrm{mg} \mathrm{L}$ "1 (fluorescence detection). The limits of quantification were $6 \mathrm{mg} \mathrm{L}$ "1 (UV detection) and $0.45 \mathrm{mg} \mathrm{L}$ (fluorescence detection). Thus, this analytical method is suitable for sensitive lactose quantification in milk systems of less than $10 \mathrm{mg} \mathrm{L} " 1$ (Sarah et al. 2012).

\section{Sensory analysis of lactose hydrolysed milk using partially purified $\beta$-galactosidase enzyme extracted from different cultures}

During hydrolysing lactose in milk, lactose is broken down into glucose and galactose. Hence, the content of glucose in the milk becomes high. Since sweetening index of glucose is five times higher than that of lactose, and sweetening index of galactose is four times higher than that of lactose, and the milk tastes sweeter without adding any sweetening substance due to glucose and galactose content. It should be free from undesirable off flavors like cowy, barny, weedy, foreign, acidic, malty, lacks freshness and other extraneous matter. Lactose hydrolysed milk samples were subjected to judging and grading for various sensory 
attributes viz. i) Color and Appearance, ii) Odour (roma), iii) acidity, iv) Flavour \& taste and v) Body (consistency) vi) Overall acceptability on the basis of 100 point score card as per BIS (IS:7768, 1975). Six combinations were decided (3: cultures, 1: Commercially available enzyme (CAE) and one positive and negative control) in this study.

The variations in color and appearance scores of lactose hydrolysed milk were given in Fig. 5. Lowest score was observed in Sample F (7.61). The average color and appearance score was 8.54. During sensory evaluation, Samples B, C and E exhibited highest score followed by D, A and F. The average color and appearance score was ranged from 7.61 to 8.89 . The variations in odour scores of lactose hydrolysed milk were given in Fig. 5. Lowest score was observed in Sample F (16.0). The average odour score was 16.44. During sensory evaluation, Samples B shown highest score followed by C, A, D, E and F. The average odour score was ranged from 16.0 to 17.48 . The variations in flavour \& taste scores of lactose hydrolysed milk were given in Fig. 5. Lowest score was observed in Sample D (32.41). The average flavour and taste score was 33.83. During sensory evaluation, Samples B exhibited the highest score followed by A, F, C, E and F. The average flavour \& taste score was ranged from 32.41 to 37.04. The variations in body (consistency) scores of lactose hydrolysed milk were given in Fig. 5. Lowest score was observed in Sample A (25.52). The average body (consistency) score was 26.15. During sensory evaluation, Samples B had shown highest score followed by C, D, E, F and A. The average body (consistency) score was ranged from 25.52 to 26.93 . The variations in overall acceptability scores of lactose hydrolysed milk were given in Fig. 5. Lowest score was observed in Sample F (82.50). The average overall acceptability score was 84.95 . During sensory evaluation, Samples B had shown highest score followed by A, $\mathrm{C}, \mathrm{E}, \mathrm{D}$ and $\mathrm{F}$. The overall acceptability score was ranged from 82.50 to 90.33 .

Adhikari et al. (2010) reported the sensory characteristics of ultrapasteurized (UP) lactose-free milk of different fat contents, and compared them with normal milk. Nine milk samples (six UP lactose-free and three regular) containing 0,2 or $3 \mathrm{~g}$ milk fat $/ 100$ $\mathrm{ml}$ were tested by a descriptive panel. A consumer test with three UP lactose-free milk and three regular samples was also conducted. The skim milks were found to be lacking in freshness and the dairy notes were lower compared to the higher-fat-content milks. The UP lactose-free milks were different from the regular milk because of higher intensities of cooked, processed, and sweet attributes. This results is similar as our study. In another study, Nielsen et al. (2017) studied on the effects of storage conditions on the shelf-life of hydrolysed-lactose ultra-high-temperature (UHT) milk was evaluated using proteomics. Lactose content was initially reduced to approximately $40 \%$ by ultra and nano filtration before hydrolysis. Sensory descriptive analysis was used to describe the sensory characteristics of the milk during storage. Bitterness intensity significantly increased over time and was correlated with the level of peptides released via either enzymatic (proteolytic side activity of the enzyme used in lactose hydrolysis) or non-enzymatic pathways (heat and storage induction). This study demostrated a relationship between proteolysis and decreased shelf-life of hydrolysed-lactose UHT milk compared with conventional UHT milk.

Based on above sensory scores, B, A, and C cultures showed highest sensory score and they were more acceptable compared to $\mathrm{D}, \mathrm{E}$ and $\mathrm{F}$ after $12 \mathrm{~h}$ of incubation at $37^{\circ} \mathrm{C}$ by adding $2 \%$ partially purified $\beta$-galactosidase enzyme in sterilized reconstituted skim milk. However, B, A and C were found acceptable.

\section{Conclusions}

L.helveticus MTCC 5463 (V3) produced maximium $\beta$ galactosidase activity at $\mathrm{pH} 6.5$ and temperature i.e. $40^{\circ} \mathrm{C}$. During evaluation of lactose hydrolysis using partially purified $\beta$ galactosidase enzyme, $\mathrm{V} 3$ showed maximum reduction of lactose and maximum production of glucose and galactose at $2 \%$ rate of $\beta$-galactosidase upto $12 \mathrm{~h}$ of incubation. Based on sensory score, B (Commercially available enzyme sample), A (Reconstituted sterilized skim milk), and C (Partially purified $\beta$-galactosidase produced from V3) were found acceptable. Therefore, $\beta$ galactosidase extracted from Lactobacillus cultures could be used for the production of lactose hydrolysed milk.

\section{Acknowledgements}

I am thankful to Dr. V.B. Darji, Professor, Department of Agricultural Science, CAIT, AAU, Anand for helping in data analysis using statistical methods. I am also thankful to Anand Agricultural University for allowing me to study my $\mathrm{M}$. Tech research work in Dairy Microbiology Department, SMC College of Dairy Science, Anand.

\section{References}

Adhikari K, Dooley L, Chambers E, Bhumiratana N (2010) Sensory characteristics of commercial lactose-free milks manufactured in the United States. Food Science and Technology 43:113-118

Bosso A, Morioka LR, Santos LF, Suguimoto HH (2016) Lactose hydrolysis potential and thermal stability of commercial $\beta$-galactosidase in UHT and skimmed milk. Food Science and Technology (Campinas) 36(1):159-165

Carevic M, Vukasinovic-Sekulic M, Corovic M, Rogniaux H, Ropartz D, Velickovic D, Bezbradica D (2018) Evaluation of $\beta$-galactosidase from Lactobacillus acidophilus as biocatalyst for galactooligosaccharides synthesis: Product structural characterization and enzyme immobilization. Journal of Bioscience and Bioengineering 126(6): 697-704

Chanalia P, Gandhi D, Attri P, Dhanda S (2018) Purification and characterization of $\beta$-galactosidase from probiotic Pediococcus acidilactici and its use in milk lactose hydrolysis and galactooligosaccharide synthesis. Bioorganic Chemistry 77: 176189 
Haider T, Husain Q (2008) Concanavalin A layered calcium alginatestarch beads immobilized beta galactosidase as a therapeutic agent for lactose intolerant patients. International Journal of Pharmaceutics 359: 1-6

Husain Q (2010) Beta galactosidases and their potential applications. Critical Reviews in Biotechnology 30(1):41-62

IS: 7768 (1975). Method for sensory evaluation of milk, BIS, Manak Bhavan, New Delhi.

Jensen S, Jansson T, Eggers N, Clausen MR, Larsen LB, Jensen HB et al (2015) Storage-induced changes in the sensory characteristics and volatiles of conventional and lactose-hydrolyzed UHT processed milk. European Food Research and Technology 240:1247-1257

Makwana S, Hati S, Parmer H, Aparnathi KD (2017) Process Optimization for the Production of $\beta$-Galactosidase Using Potential Lactobacillus Cultures. International Journal of Current Microbiology and Applied Sciences 6(8):1454-1469

Nielsen S D, Jansson T, Le T, Larsen LB (2017) Correlation between sensory properties and peptides derived from lactose-hydrolyzed UHT milk during Storage. International Dairy Journal 1-9

Oliveira C, Guimaraes PM, Domingues L (2011) Recombinant microbial systems for improved beta-galactosidase production and biotechnological applications. Biotechnology Advances 29(6):600609

Papadimitriou CG, Vafopoulo-Mastrojiannaki A et al (2007). Identification of peptides in traditional and probiotic sheep milk yoghurt with angiotensin 1-converting enzyme (ACE) activity. Food Chemistry 14: $647-656$

Picard C, Fioramonti J, Francois A, Robinson T, Neant F, Matuchansky C (2005) Review article: bifidobacteria as probiotic agents physiological effects and clinical benefits. Alimentary Pharmacology and Therapeutics 22: 495-512
Prasad LN, Ghosh BC, Sherkat F et al (2013) Extraction and characterisation of $\beta$-galactosidase produced by Bifidobacterium animalis spp. lactis $\mathrm{Bb} 12$ and Lactobacillus delbrueckii spp. bulgaricus ATCC 11842 grown in whey. International Food Research Journal 20:487-494

Rajakala P, Karthigai SP (2006) The Effect of pH, temperature and alkali metal ions on the hydrolsis of whey lactose catalysed by $\beta$ galactosidase from Kluyveromyces marxianus. International Journal of Dairy Science 1:167-172

Rodriguez-Figureroa JC, Gonzalez-Cordova AF, Torres-Llanez MJ (2012) Novel angiotensin 1-converting enzyme inhibitory peptides produced in fermented milk by specific wild Lactococcus lactis strains. Journal of Dairy Science 95:5536-5543

Sarah E, Anzman T, Fischer L (2012) Quantification of lactose using ionpair RP-HPLC during enzymatic lactose hydrolysis of skim milk. Food Chemistry 135(4):2393-2396

Sharma S, Singh P (2014) Isolation and characterization of Galactosidase enzyme producing microbe and optimization of its enzyme activity under different culture condition. International Journal of Current Microbiology and Applied Sciences 3: 148-155

Ustok FI, Tari C, Harsa S (2010) Biochemical and thermal properties of $\beta$-galactosidase enzymes produced by artisanal yoghurt cultures. Journal of Food Chemistry 119: 1114-1120

Xavier JR., Ramana KV, Sharma RK (2018) $\beta$ galactosidase: Biotechnological applications in food processing. Journal of Food Biochemistry 42(5): 12564

Xinmin W, Zhang R, Zhihuaa B, Wang Y, Jiang T (2008) Determination of glucosamine and lactose in milk-based formulae by highperformance liquid chromatography. Journal of Food Composition and Analysis 21:255-258 